\title{
The Green Snake and Red-bellied Snake in Saskatchewan
}

by Francis R. Cook, National Museum of Canada, Ottawa, and Robert W. Nero, Saskatchewan Museum of Natural History, Regina

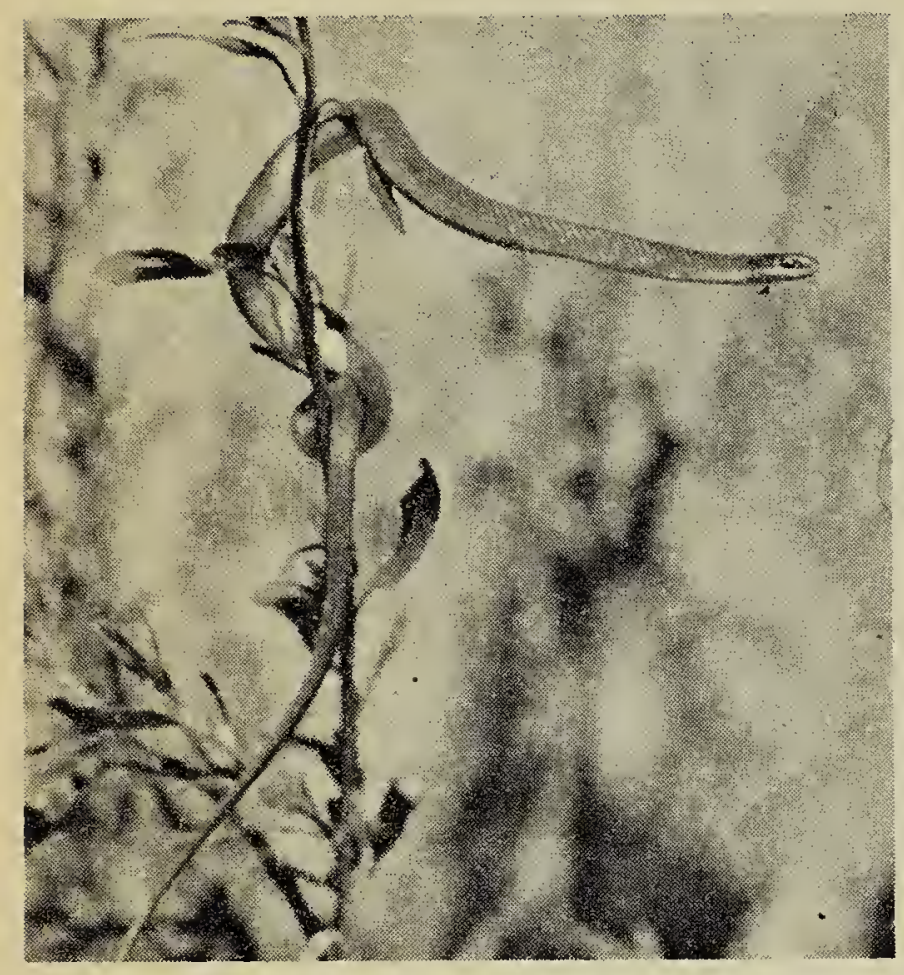

Photo by F. Lahrman, M.M.N.H. Smooth Greien Snake

Although Saskatchewan has only eight species of snakes, accurate knowledge of their distribution is still incomplete. The two smallest, the Green Snake (Opheodrys vernalis) and the Red-bellied Snake (Storeria occipitomaculata) are perhaps the least known of all. Both have been occasionally collected in the province but no definite localities have been recorded in the Blue Jay. Logier and Toner (1961) were the first authorities to cite the Saskatchewan records which have been gradually accumulating, based mainly on Saskatchewan Museum of Natural History specimens. Previous range maps of these species had omitted Saskatchewan for both (Logier and Toner, 1955) or plotted only the extreme southeast corner of the province for the Green Snake and omitted the Red-bellied Snake (Conant, 1958).

A recent collection of the Green Snake, extending its range in Canada to mid-Saskatchewan, has emphasized this lack and prompted the authors to draw together the following notes on identification, habitat and distribution. It is hoped that readers will be alerted for these species and report new records. Specimens are also needed as too few are available to permit a thorough understanding of the variation within the province for either species.

The Red-bellied Snake is brown, gray or black above, usually with a lighter stripe down the centre of the back and two darker lines parallel to it on each side. One specimen collected in Manitoba last summer had a light brown centre stripe and grey sides. This color phase may also occur in Saskatchewan. All Saskatchewan specimens seen to date have rust-brown sides and a lighter middorsal stripe. Regardless of the color variation on the back and sides individuals may always be identified by their bright red underside and the presence of three yellow spots on the neck.

In some areas where it occurs this species is called the "copper snake" and regarded as very poisonous. This, however, is pure fancy. In the Canadian prairies the only poisonous species is the Prairie Rattlesnake which may be identified by the rattles on the tail.

Red-bellied Snakes do not exceed one and a half feet in length, and most specimens are much smaller. Saskatchewan examples ranged from nine and a half to ten inches. It is primarily a snake of woodlands, oc-

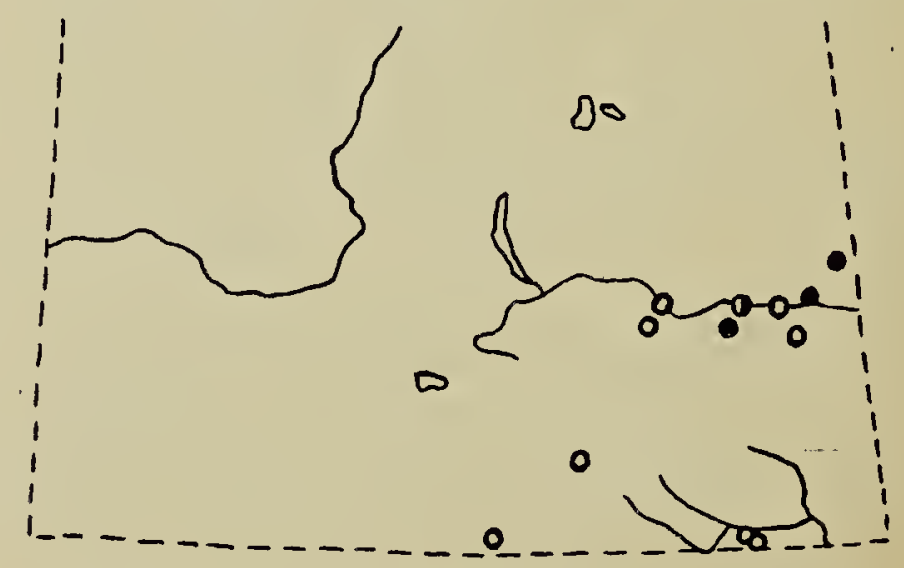

Distribution of the Green Snake (Opheadrys vernalis) and the Red-bellied Snake (Storeria occipitcmaculata). Open circles are localities for the Green Snake, closed circles localities for the Red-bellied Snake. Half open circles are localities where both species have been rcorded. 
curring over most of southeastern Canada and the eastern United States. Few are seen in the open, but individuals may often be collected under boards, stones and similar cover.

Logier and Toner (1961, p. 64) record the species from Crooked Lake, Grenfell, Hazelcliffe and Langenburg on the basis of specimens in the Saskatchewan Museum of Natural History and the University of Saskatchewan collection.

The Green Snake is bright green above and white or yellowish below. It is only slightly larger than the Red-bellied Snake, rarely reaching two feet in total length. Saskatchewan specimens vary from eleven to sixteen inches.

Two subspecies are recognized, an eastern form, Opheodrys vernalis vernalis, which has 130 or fewer ventral scales in males, 139 or fewer in females; and a western form, Opheodrys vernalis blanchardi which has a higher ventral scale count. Saskatchewan individuals examined had counts of 129 and 130 for males and 136, 138 and 142 for females. Manitoba specimens having similar intermediate counts were considered intergrades between the two subspecies by Grobman (1941). At least until more specimens are available, Saskatchewan individuals are best placed in the same category. Logier and Toner (1961, p. 76) regarded the Saskatchewan form as $O$. v. blanchardi on the basis of geographic range, but had not examined the existing specimens.

The Green Snake is a snake of moist grasslands and is absent in arid regions. Owing to its protective coloration it is rarely seen in the open, but may be found under various suitable cover as in the preceding species.

The known western limit of the Green Snake in Canada was established by a specimen collected by $\mathrm{Mr}$. Glenford Bellrose of Coronach. It was taken on July 12,1960 , on the SE $1 / 4-13-2-27 \mathrm{~W} 2$, near the doorstep of a farmhouse. The area surrounding the farmyard is cultivated farmland and one-half mile east of the farm is pasture land with a creek flowing through it. Another specimen was reported by $\mathrm{Mr}$. Bellrose on the $\mathrm{NE} 1 / 4-30-2-25$ W2 in the same type of area, beside a spring where water is available at all times.

Locality records cited by Logier and Toner (1961, p. 76) are Ceylon, Crooked Lake, Katepwa Beach, North Portal, and Roche Percee and are based on specimens in the Saskatchewan Museum of Natural History and National Museum of Canada. Additional specimens from Indian Head, Round Lake, and Whitewood are recorded by the Saskatchewan Museum of Natural History.

\section{REFERENCES}

CONANT, ROGER, 1958. A Field Guide to Reptiles and Amphibians of the United States and Canada east of the 100th Meridian. Houghton, Mifflin Co., Boston.

GROBMAN, A. B., 1941. A contribution to the knowledge of the variation in Opheodrys vernalis (Horton) with the description of a new subspecies. Misc. Pub. Mus. of Zool. Univ. Mich. No. 50, pp. 1-38.

LOGIER, E. B. S., and G. C. TONER, 1955. Check-List of the Amphibians and Reptiles of Canada and Alaska. Roy. Ont. Mus. Zool. Contrib. No. 41.

LOGIER, E. B. S., and G. C. Toner, 1961. Cheok-List of the Amphibians and Reptiles of Canada and Alaska. 2nd Ed. Life Sciences Division, Royal Ontario Museum, Contribution No. 53.

\title{
Phyllopod Crustaceans
}

\author{
by Hugh McLaughlin, Lewvan
}

\begin{abstract}
"Phyllopod crustaceans are among the most graceful and attractive inhabitants of fresh water pools." So begins a chapter on this group of crustaceans in Fresh Water Biology by Ward and Whipple. I would suggest that introduction to this type of water life begin on hands and knees beside a roadside ditch in early spring. Fairy Shrimp will be there and can be depended on to fascinate any student of nature.

Crustaceans are essentially aquatic
\end{abstract}

arthropods. The name tells that they are chitinous-armoured creatures with jointed legs. The higher crustaceans, including the lobsters and crayfish, are grouped together as the Malacostraca. The smaller crustacea may be grouped together as the Entomostraca. Among the most primitive and most fascinating of the Entomostraca are the Phyllopoda or Branchiopoda, the gill-footed crustacea. The leaf-life appendages serve both for locomotion and for breathing 